\title{
Endotoxin-Tolerance to the Cytotoxicity toward a Macrophage-Like Cell Line, J774.1, Induced by Lipopolysaccharide and Cycloheximide: Role of p38 MAPK in Induction of the Cytotoxicity
}

\author{
Hisae KARAHASHI ${ }^{a}$ and Fumio AmANo*,a,b \\ ${ }^{a}$ Department of Biochemistry and Cell Biology, National Institute of Infectious Diseases; Toyama, Shinjuku-ku, Tokyo \\ 162-8640, Japan: and ${ }^{b}$ Department of Hygienic Chemistry, Osaka University of Pharmaceutical Sciences; 4-20-1 \\ Nasahara, Takatsuki, Osaka 569-1094, Japan. Received April 21, 2003; accepted June 2, 2003
}

\begin{abstract}
Novel endotoxin-tolerance was observed to the cytotoxycity induced by lipopolysaccharide (LPS) and cycloheximide (CHX) in an LPS-treated macrophage-like cell line, J774.1; preincubation of macrophages with low doses of LPS alone for $90 \mathrm{~min}$ almost completely prevented the apoptotic death in the second incubation with LPS and CHX. The first challenge of LPS affected neither the subsequent LPS binding nor the expression of CD14. Instead, phosphorylation of mitogen-activated proteinkinase (MAP kinases) involving p38, extracellular signal-regulated kinase 1/2 (Erk1/Erk2) and c-jun N-terminal kinase (JNK) in the second incubation with LPS and CHX were suppressed, suggesting that this endotoxin-tolerance was caused by down-regulation of LPS-signaling pathway leading to MAP kinase activation. On the other hand, LPS-induced cytotoxicity seemed to depend on the sustained phosphorylation of p38 MAP kinase; the addition of SB202190, an inhibitor of p38 MAP kinase activity, in the first incubation with LPS caused induction of the cytotoxicity in the second incubation with LPS and CHX or CHX alone, under which conditions increased phosphorylation of p38 MAP kinase without that of Erk1/Erk2 or JNK was observed. These results suggest that down-regulation of the p38 MAP kinase cascade in the first incubation with LPS is linked to induction of endotoxin-tolerance to the cytotoxicity with higher doses of LPS and CHX.
\end{abstract}

Key words tolerance; cytotoxicity; lipopolysaccharide; monocyte; macrophage; p38 mitogen-activated protein (MAP) kinase

Lipopolysaccharide (LPS) is one of the major components of the outer membrane of Gram-negative bacteria, and is known as one of the strongest activators of macrophages. ${ }^{1,2}$ Activated macrophages produce such cytokines as tumor necrosis factor $\alpha$ (TNF- $\alpha$ ), interleukin-1 (IL-1) and IL-6, $\left.{ }^{3-6}\right)$ or prostaglandins or nitric oxide (NO), ${ }^{7,8)}$ and overproduction of these materials by the activated macrophages has been suggested not only to cause endotoxin shock ${ }^{9-17)}$ but also to regulate macrophage functions.

One of the characteristic features of LPS-signaling is endotoxin-tolerance; the pre-administration of a low dose of LPS induces resistance to the lethality of high doses of LPS in the presence or absence of galactosamine in mice. ${ }^{18)}$ This phenomenon has been explained as a result of down-regulation of cytokine production by macrophages. For a macrophage culture in vitro, similar results were obtained on preincubation of the macrophages with a low dose of LPS, which resulted in decreases in TNF- $\alpha$ mRNA expression and subsequent production of TNF- $\alpha$ induced by a second high dose of LPS. ${ }^{3,19,20)}$ These results suggest that LPS-tolerance is mainly due to the down-regulation of signal transduction by LPS in macrophages through the production of cytokines. However, the molecular mechanisms underlying the induction and regulation of LPS-tolerance of a variety of macrophage functions remain largely unknown.

We found the cytotoxic effect of LPS toward a macrophage-like cell line, J774.1, in the presence of a protein synthesis inhibitor, cycloheximide (CHX). ${ }^{21)}$ This cytotoxicity accompanied apoptosis characterized by the cleavage of poly(ADP-ribose) polymerase (PARP), formation of a DNA ladder, ${ }^{22)}$ or activation of caspase-3, a key enzyme inducing this cytotoxicity. ${ }^{23)}$ However, this cytotoxicity did not accompany the expression of such activated macrophage phenotypes as the production of TNF- $\alpha$, IL- $1 \beta$ or prostaglandins due to the presence of a protein synthesis inhibitor, $\mathrm{CHX}^{21)}$ Instead, dysregulation of the LPS-signaling cascade by CHX was suggested to change activation pathways to a death one in macrophages. ${ }^{22}$

In this report, we demonstrate novel endotoxin-tolerance to the macrophage cytotoxicity induced by LPS and CHX, which seems to be regulated by mechanisms different from those involving negative-feedback by the activated macrophage products. Preincubation of macrophages with a low dose of LPS for as little as 90 min caused almost complete inhibition of the apoptotic cell damage in the second incubation with a high dose of LPS in the presence of CHX. This tolerance was not mediated by a soluble factor(s) in the LPStreated macrophages, but was regulated intracellularly.

We also examined the possible role of p38 MAP kinase in the LPS-induced cytotoxicity with CHX. This kinase is a member of the MAP kinase family whose activity is regulated through phosphorylation at 180Tyr and $182 \mathrm{Thr}$ by upstream kinases such as Mitogen-activated kinase kinase $3 / \mathrm{mi}-$ togen-activated kinase kinase 6 (MKK3/MKK6) ${ }^{24)}$ in LPStreated macrophages, and the sustained phosphorylation of p38 MAP kinase was recently suggested to be a candidate as to LPS-induced cytotoxicity. ${ }^{25)}$ We also provide evidence that the endotoxin-tolerance to LPS-induced cytotoxicity is due to down-regulation of the LPS-induced p38 MAP kinase cascade among those of MAP kinases.

\section{MATERIALS AND METHODS}

Cell Culture Culturing of the JA-4 cell line, an LPSsensitive subline of a murine macrophage-like cell line, J774.1, was performed as described previously. ${ }^{21)}$ In brief, the cells were maintained and cultured in $10 \mathrm{ml}$ of Ham's F12 medium (Flow Laboratories, McLean, VA, U.S.A.) sup- 
plemented with $10 \%$ heat-inactivated fetal bovine serum (Gibco, Grand Island, NY, U.S.A.), $50 \mathrm{U} / \mathrm{ml}$ of penicillin and $50 \mu \mathrm{g} / \mathrm{ml}$ of streptomycin (Flow Laboratories) in a $100 \mathrm{~mm}$ plastic dish (Falcon \#1001; Becton Dickinson, Lincoln Park, NJ, U.S.A.) at $37^{\circ}$ in a $\mathrm{CO}_{2}$ incubator $\left(5 \% \mathrm{CO}_{2}-95 \%\right.$ humidified air).

Induction of Tolerance and Assaying of Cytotoxicity The cytotoxic effect of LPS was examined using JA-4 cells as described previously. ${ }^{21}$ The cells were seeded at $2 \times 10^{5} \mathrm{cells} / \mathrm{well} / 0.5 \mathrm{ml}$ of the culture medium described above on flat-bottomed plates with 24-well clusters (Coster \#3524; Cambridge, MA, U.S.A.), and then incubated overnight at $37^{\circ} \mathrm{C}$. The medium was replaced with $0.5 \mathrm{ml}$ of fresh medium supplemented without or with $10 \mathrm{ng} / \mathrm{ml}$ LPS (LPS from Escherichia coli O55 : B5; Sigma, St. Louis, MO, U.S.A.), and then the cells were incubated for $90 \mathrm{~min}$. Then the cells were washed with fresh medium six times to remove LPS completely, and reincubated in $0.5 \mathrm{ml}$ of fresh medium supplemented with $100 \mathrm{ng} / \mathrm{ml}$ LPS and $10 \mu \mathrm{g} / \mathrm{ml} \mathrm{CHX}$ (Wako Pure Chemicals, Osaka) at $37^{\circ} \mathrm{C}$ for a further $4 \mathrm{~h}$. The culture supernatant was collected and then centrifuged at $10000 \mathrm{rpm}$ for $1 \mathrm{~min}$ at $4{ }^{\circ} \mathrm{C}$. Aliquots $(300 \mu \mathrm{l})$ of the resultant supernatant were regarded as the cell-free supernatant and used for the Lactate dehydrogenase (LDH) assay. As a negative control, the culture supernatant was collected at zero time incubation and used to determine the background release of LDH. To determine the total LDH activity, cultures of non-treated cells were mixed with a final concentration of $0.1 \%$ Triton X-100 at the end of the incubation at $37^{\circ} \mathrm{C}$ for $4 \mathrm{~h}$, and then incubated for an additional $30 \mathrm{~min}$ at $37^{\circ} \mathrm{C}$ for complete lysis of the cells. The culture supernatant of these cells was centrifuged as described above and the resultant supernatant was used for the LDH assay. LDH activity was determined with an assay kit for LDH (Kyokuto Pharmaceutical Co., Tokyo), according to the manufacturer's protocol. Cytotoxicity was expressed as \% of the total activity according to the following formula:

$$
\% \text { of total }=\frac{(\text { experimental release })-(\text { background release })}{(\text { total activity })} \times 100
$$

TUNEL (TdT-Mediated Nucleotide 3'-OH End Labeling) Staining Cells were seeded onto a slide glass (Celline Associations, Inc.), incubated overnight, treated with $10 \mathrm{ng} / \mathrm{ml}$ LPS in fresh medium for $90 \mathrm{~min}$, washed six times, and then reincubated with $100 \mathrm{ng} / \mathrm{ml}$ LPS and $10 \mu \mathrm{g} / \mathrm{ml} \mathrm{CHX}$ for $2 \mathrm{~h}$. Finally the cells were fixed with 3\% formaldehyde in

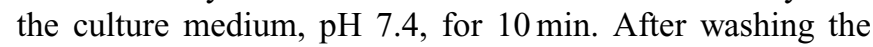
fixed cells with phosphate-buffered saline without divalent cations $(\mathrm{PBS}(-))$ repeatedly, they were permeabilized with $0.1 \%$ Triton $\mathrm{X}-100$ in $\mathrm{PBS}(-)$ at room temperature for 10 min, followed by washing with PBS(-). TUNEL staining was performed with an In Situ Cell Death Detection Kit, TMR Red (Boehringer Mannheim GmbH, Mannheim, Germany), according to the manufacturer's protocol based on TdT-mediated polymerization of nucleotides to free $3^{\prime}-\mathrm{OH}$ DNA ends (TUNEL reaction) with TMR Red-conjugated nucleotides. Detection of TUNEL-positive cells was performed on the basis of the fluorescence of TMR red-conjugated nucleotides under a confocal microscope. A Carl Zeiss Laser Scanning Microscope, model LSM 510, comprising a fluo- rescent microscope (Carl Zeiss, model Axiovert 100M) and a C-Apochromat objective lens, was operated following the instruction manual with an excitation wavelength at $543 \mathrm{~nm}$ (UV laser for TMR Red) and an emission wavelength longer than $560 \mathrm{~nm}$, respectively. The results were analyzed with basic LSM510 software, and photographs were taken under either fluorescent (TMR Red) or transmitted light (DIC; differential interference contrast) in random fields, and more than 150 cells were observed in each sample in repeated experiments.

FACScan Analysis JA-4 cells were seeded at $1.0 \times 10^{6}$ cells $/ 1 \mathrm{ml} / \mathrm{dish}$ (Iwaki \#3000-035), and then incubated at $37^{\circ} \mathrm{C}$ overnight. The medium was replaced with $1 \mathrm{ml}$ of fresh medium containing $10 \mathrm{ng} / \mathrm{ml}$ LPS, and then the cells were incubated for $90 \mathrm{~min}$. Then the culture medium was replaced with ice-cold FACScan buffer comprising $0.1 \%$ BSA and $0.1 \%$ sodium azide in $\mathrm{PBS}(-)$, and the cells were scraped off from the dish, collected by centrifugation and then washed with FACScan buffer. Then the cells were incubated on ice with a monoclonal anti-mouse CD14 antibody (PharMingen, San Diego, CA, U.S.A.) at 1:125 dilution for $30 \mathrm{~min}$, or with $100 \mathrm{ng} / \mathrm{ml}$ FITC-LPS (Sigma) for $4 \mathrm{~h}$. The cells that had reacted with the anti-mouse CD14 antibody were subsequently washed with FACSan buffer, followed by incubation with FITC-labeled anti-rabbit IgG (American Quarex, La Mirada, CA, U.S.A.) for $30 \mathrm{~min}$ on ice. Finally, the cells were washed with FACScan buffer repeatedly, and the FITC on the cell surface was detected with FACScan (Beckton Dickinson Immunocytometry Systems; San Jose, CA, U.S.A.) and the results were analyzed with the Cell Quest $^{\mathrm{TM}}$ Program (Beckton Dickinson).

Protein Kinase Assay and Immunoblotting JA-4 cells were seeded at $4.0 \times 10^{6} \mathrm{cells} / 8 \mathrm{ml} / \mathrm{dish}$ (Corning \#25010), and then incubated at $37^{\circ} \mathrm{C}$ overnight. The medium was replaced with $5 \mathrm{ml}$ of fresh medium, and then $100 \mathrm{ng} / \mathrm{ml}$ LPS and $10 \mu \mathrm{g} / \mathrm{ml} \mathrm{CHX} \mathrm{were} \mathrm{added.} \mathrm{After} \mathrm{incubation} \mathrm{for} \mathrm{various}$ times, the cells were chilled on ice. Then the cells were washed with PBS(-) twice, scraped off, pelleted by centrifugation at $4{ }^{\circ} \mathrm{C}$ at $10000 \mathrm{rpm}$ briefly, and suspended in $100 \mu \mathrm{l}$ of the phosphorylation lysis buffer comprising $0.1 \mathrm{~mm}$ EDTA, $10 \mathrm{~mm} \mathrm{NaF}, 1 \mathrm{~mm} \mathrm{Na}_{3} \mathrm{VO}_{4}, 1 \%$ aprotinin and $0.1 \%$ Triton X-100 in $20 \mathrm{~mm}$ Tris- $\mathrm{HCl}$ (pH 7.5). After standing on ice for $30 \mathrm{~min}$, the cells were centrifuged at $10000 \mathrm{rpm}$ for $1 \mathrm{~min}$ at $4{ }^{\circ} \mathrm{C}$, and the resultant supernatant was used as the cell extract. For immunoprecipitation, $150 \mu \mathrm{g}$ protein of the cell extract was diluted to $1.5 \mu \mathrm{g} / \mu \mathrm{l}$ with buffer A (phosphorylation lysis buffer $+150 \mathrm{~mm} \mathrm{NaCl}$ ) for mitogen-activated protein kinase-activated protein kinase (MAPKAPK2). The cell extract was incubated with protein G-Sepharose beads (Amersham-Pharmacia Biotech, Uppsala, Sweden) on ice for $10 \mathrm{~min}$ and subsequently centrifuged to abolish non-specific binding of proteins to protein $\mathrm{G}$. Then $100 \mu \mathrm{l}$ aliquots of the resultant supernatant were mixed with $1.2 \mu \mathrm{g}$ of anti-MAPKAPK2 antibodies (Upstate Biotechnology, Lake Placid, NY, U.S.A.), and the immunoprecipitation reaction was performed at $4{ }^{\circ} \mathrm{C}$ for $16 \mathrm{~h}$ with continuous mixing. The immune complex was reacted with protein G-Sepharose beads by incubation at $4{ }^{\circ} \mathrm{C}$ for an additional $1 \mathrm{~h}$, and the beads were precipitated by centrifugation, washed with buffer A, buffer B (phosphorylation lysis buffer $+1 \mathrm{M} \mathrm{NaCl}$ ), and then buffer A. Finally the beads were washed again with the kinase reac- 
tion buffer (-ATP) as described below, and then suspended in $18 \mu \mathrm{l}$ of the kinase reaction buffer comprising $10 \mathrm{mM} \mathrm{MgCl}_{2}$, $0.5 \mathrm{~mm}$ EGTA $3 \mathrm{Na}, 4 \mathrm{~mm}$ DTT, $2.5 \mu \mathrm{M}$ ATP and $0.17 \mu \mathrm{M}[\gamma-$ $\left.{ }^{32} \mathrm{P}\right]$ ATP $(10 \mu \mathrm{Ci}, \mathrm{NEN})$ in $20 \mathrm{~mm}$ Tris- $\mathrm{HCl}, \mathrm{pH}$ 7.5. The kinase reaction was started by the addition of $2.6 \mu \mathrm{g}$ hsp27 (StressGen Biotechnologies Corp., Victoria, BC, Canada), followed by incubation at $28^{\circ} \mathrm{C}$ for $30 \mathrm{~min}$, and terminated by the addition of $3 \times$ SDS-sample buffer finally comprising $1 \%$ SDS, 5\% 2-mercaptoethanol, 20\% glycerol, 1 mM EDTA and $0.05 \%$ bromophenol blue, and then boiling at $95{ }^{\circ} \mathrm{C}$ for 5 min. Samples were loaded onto $5-20 \%$ gradient gels (PAGEL; ATTO, Tokyo), and the gels were dried and visualized by autoradiography.

For Western blotting, 50, 75 and $100 \mu \mathrm{g}$ aliquots of cell extracts were treated with the SDS-sample buffer for $\mathrm{p} 38$, JNK and Erk1/Erk2, respectively, and then boiled at $95^{\circ} \mathrm{C}$ for $5 \mathrm{~min}$. Samples were loaded onto a $5-20 \%$ gradient gel, developed, and then electrotransferred to an Immobilon PVDF membrane (Millipore) at $30 \mathrm{~V}$ overnight and then at $100 \mathrm{~V}$ for $30 \mathrm{~min}$. After blocking of the filter with $30 \mathrm{mg} / \mathrm{ml}$ milk casein (Snow Brand, Sapporo), phosphorylated p38, phosphorylated Erk1/Erk2, and phosphorylated JNK were detected with anti-dual-phosphorylated p38 MAPK, antidual-phosphorylated Erk1/Erk2, and anti-dual-phosphory- lated JNK antibodies (New England BioLabs, Beverly, MA, U.S.A.), respectively, according to the manufacturer's protocol. For the detection of phosphorylated hsp27 (phospho Ser ${ }^{15}$-hsp27), $50 \mu \mathrm{g}$ cell extract proteins after transfer to a membrane were reacted with a polyclonal anti-phospho Ser $^{15}$-hsp27 antibody, ${ }^{25)}$ and then with an HRP-conjugated anti-rabbit IgG antibody (New England Biolabs), as described above.

\section{RESULTS}

Induction of Endotoxin-Tolerance to the Cytotoxicity Induced by LPS and CHX Remarkable damage to macrophages was observed on treatment of the cells with LPS and CHX for $4 \mathrm{~h}$ (Fig. 1A (b)), which was associated with the release of lactate dehydrogenase (LDH) from the cells into the culture medium, a marker of cell damage due to dysfunctioning of the cell membrane barrier. ${ }^{23)}$ However, preincubation of the cells with $10 \mathrm{ng} / \mathrm{ml}$ LPS for $90 \mathrm{~min}$ followed by repeated washing of the cells prevented the cell damage on subsequent incubation with $100 \mathrm{ng} / \mathrm{ml}$ LPS and $10 \mu \mathrm{g} / \mathrm{ml}$ CHX (Fig. 1A (d)). These results imply that preincubation of macrophages with a low dose of LPS induces resistance to the cytotoxicity in the second incubation with a
(A)
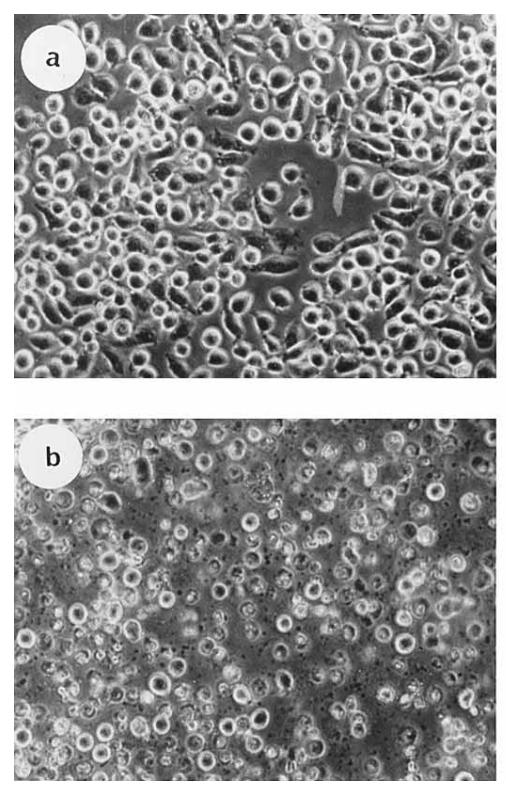

(B)
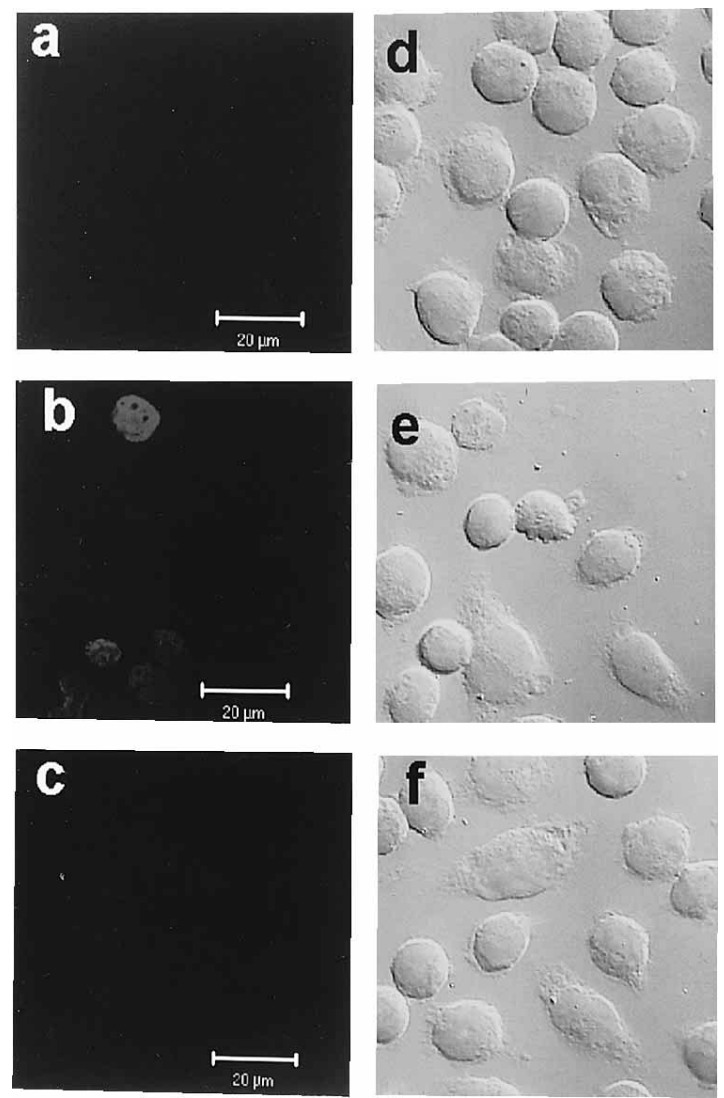

Fig. 1. Inhibition of Cell Damage and Apoptosis Induced by LPS and CHX on Preincubation with a Low Concentration of LPS

(A) Cells were treated without (c) or with $10 \mathrm{ng} / \mathrm{ml}$ LPS (d) at $37^{\circ} \mathrm{C}$ for $90 \mathrm{~min}$, and then washed with fresh medium to remove LPS. Then the cells were incubated with (c, d) $100 \mathrm{ng} / \mathrm{ml} \mathrm{LPS}$ and $10 \mu \mathrm{g} / \mathrm{ml} \mathrm{CHX}$ for a further $4 \mathrm{~h}$, and photographs were taken under a phase-contrast microscope in random fields. As a negative and a positive control, cells were treated with nothing (a), or LPS and CHX (b) for $4 \mathrm{~h}$, but without preincubation for 90 min, respectively. (B) Cells were treated without (a, b, d, e) or with $10 \mathrm{ng} / \mathrm{ml}$ LPS (c, f) at $37^{\circ} \mathrm{C}$ for $90 \mathrm{~min}$ as described in (A), and then the cells were incubated without (a, d) or with $100 \mathrm{ng} / \mathrm{ml} \mathrm{LPS} \mathrm{and} 10 \mu \mathrm{g} / \mathrm{ml} \mathrm{CHX} \mathrm{(b,} \mathrm{c,} \mathrm{e,} \mathrm{f)} \mathrm{for} \mathrm{a} \mathrm{further} 2 \mathrm{~h}$. Then the cells were fixed with 3\%-formaldehyde, permealized and stained for TUNEL with an In Situ Cell Death Detection Kit, TMR red, as described in the text. The fluorescence of the TMR red incorporated into the apoptotic cells $(\mathrm{a}-\mathrm{c})$ was observed under a confocal microscope and the transmission light image was also examined as DIC images $(\mathrm{d}-\mathrm{f})$. More than 150 cells were observed in each sample and the photographs were taken under the same conditions in representative fields. Scale bar: $20 \mu \mathrm{m}$. 
high dose of LPS in the presence of CHX. We previously reported that this cytotoxicity was preceded by apoptotic changes, ${ }^{22,23)}$ and then we examined whether or not the tolerance accompanies a reduction in the population of TUNELpositive cells. As shown in Fig. 1B, non-tolerant macrophages showed TUNEL-positivity at $120 \mathrm{~min}$ after treatment with both $100 \mathrm{ng} / \mathrm{ml}$ LPS and $10 \mu \mathrm{g} / \mathrm{ml} \mathrm{CHX}$ in the second incubation (Fig. 1B (b)), preceding the cell damage at $4 \mathrm{~h}$ (Fig. 1A (c)). On the other hand, tolerant-macrophages exhibited greatly reduced the TUNEL-positivity (Fig. 1B (c)) almost to the level of the negative control without LPS and CHX (Fig. 1B (a)), suggesting that the first incubation with a low dose of LPS suppresses the LPS-induced apoptotic pathway and subsequent cell damage to the macrophages in the presence of CHX during the second incubation.

The LPS dose-dependence in the first incubation, i.e., preincubation, showed that more than $1 \mathrm{ng} / \mathrm{ml}$ LPS was necessary for resistance to the cytotoxicity in the second incubation with $100 \mathrm{ng} / \mathrm{ml}$ LPS and CHX (Fig. 2A). On the other hand, when the macrophages were treated with $1-100 \mathrm{ng} / \mathrm{ml}$ LPS in the first incubation, and then washed and subsequently incubated with $10 \mu \mathrm{g} / \mathrm{ml} \mathrm{CHX}$ alone for $4 \mathrm{~h}$ in the second incubation, no cytotoxicity was observed (data not shown), showing that LPS in the first incubation was removed from the cells to below the threshold level for induction of cell damage in the presence of $\mathrm{CHX}$ or that the addition of CHX was too late to induce cell damage after LPStreatment. ${ }^{21)}$ These results also suggest that the inhibition of LDH release in the second incubation is due to the reduced LPS response of macrophages pre-treated with a low concentration of LPS in the first incubation.

A time-course study showed that more than $90 \mathrm{~min}$ was needed for the first incubation with LPS for inhibition of the LDH release in the second incubation (Fig. 2B). On the other hand, prolonged incubation for $19 \mathrm{~h}$ gave less inhibition of LDH release than that for $90-120 \mathrm{~min}$ (data not shown), suggesting that the induction of this endotoxin-tolerance is a rather acute phenomenon, compared with that observed in the previous study on TNF- $\alpha$ production by macrophages in another laboratory. ${ }^{3)}$

It has been reported that various biological activities of LPS are due to lipid A, a hydrophobic component of LPS, and two phosphate groups and acyl moieties of lipid A are responsible for essential roles of lipid A. ${ }^{1)}$ To confirm that the tolerance to the cytotoxicity induced by LPS and CHX observed in this study is a form of endotoxin-tolerance, we examined the structure-activity relationships of LPS and lipid A analogs as to the induction of the tolerance. As shown in Fig. 3, neither detoxy-LPS (h), which lacks the acylgroups of lipid A, nor monophosphoryl lipid A (f), which lacks one phosphate group of lipid A, effectively induced the tolerance toward the cytotoxicity when used at $10 \mathrm{ng} / \mathrm{ml}$ in the first incubation. On the contrary, Salmonalla minnesota wild-type (a), Rc- (b), Rd- (c), or Re-LPS (d), di-phosphoryl lipid A (e), or E. coli. O55:B5 wild-type LPS (g), all of which have the complete structure of the lipid A component, significantly suppressed the macrophage cytotoxicity at $10 \mathrm{ng} / \mathrm{ml}$. Although monophosphoryl lipid A (f) at $100 \mathrm{ng} / \mathrm{ml}$ caused slight but significant inhibition of the LDH release, the effect was very weak compared with those of other LPS or lipid A. These results show that this tolerance to the cyto-
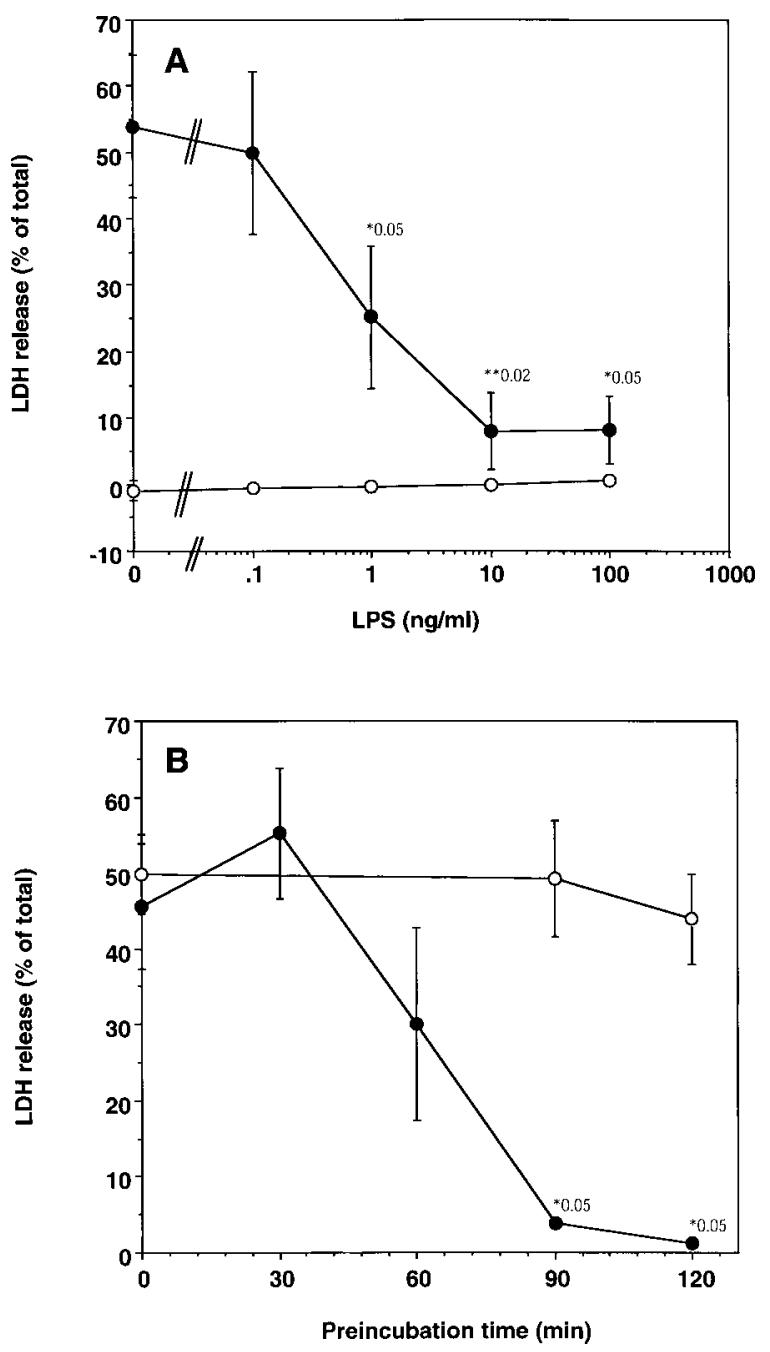

Fig. 2. Induction of Endotoxin-Tolerance to the Cytotoxicity with LPS and $\mathrm{CHX}$

(A) Effect of the LPS concentration on induction of tolerance to the cytotoxicity. Cells were preincubated with various concentrations of LPS, as shown on the abscissa, at $37^{\circ} \mathrm{C}$ for $90 \mathrm{~min}$, washed completely free of LPS, and then reincubated without (open circles) or with (closed circles) $100 \mathrm{ng} / \mathrm{ml}$ LPS and $10 \mu \mathrm{g} / \mathrm{ml} \mathrm{CHX} \mathrm{for} \mathrm{a} \mathrm{further}$ $4 \mathrm{~h}$. The release of LDH was examined as described in the text. The results are the means \pm S.E. for three independent experiments. The significance of differences was estimated by means of Student's $t$-test, and is shown as $*(p<0.05)$ or $* *(p<0.02)$. (B) Time-course of preincubation with LPS for induction of tolerance. Cells were treated without (open circles) or with (closed circles) $10 \mathrm{ng} / \mathrm{ml}$ LPS for various times, as shown on the abscissa, and then washed repeatedly. Then $100 \mathrm{ng} / \mathrm{ml}$ LPS and $10 \mu \mathrm{g} / \mathrm{ml} \mathrm{CHX}$ were added and the cells were incubated for a further $4 \mathrm{~h}$. The results are shown as described in the legend to Fig. $2 \mathrm{~A}$, and are the means \pm S.E. for three independent experiments. The significance of differences was estimated by means of Student's $t$-test, and is shown as $*(p<0.05)$.

toxicity is dependent on the structure and the activity of lipid A or those of LPS, and suggest that this phenomenon can be regarded as a new example of endotoxin-tolerance observed in macrophages.

Cell-Mediated Induction of the Tolerance to the Cytotoxicity Induced by LPS and CHX It has been suggested that LPS-activated macrophages generate various soluble factors including cytokines, and some of these factors have been reported to modulate macrophage functions in a further challenge with LPS. ${ }^{17)}$ Thus we examined the effects of soluble factors in the first incubation with LPS on the induction of the tolerance to the cytotoxicity in the second incubation. As shown in Fig. 4A, the supernatant of macrophages treated with LPS for $90 \mathrm{~min}$, which contained more than $30 \mathrm{ng} / \mathrm{ml}$ 


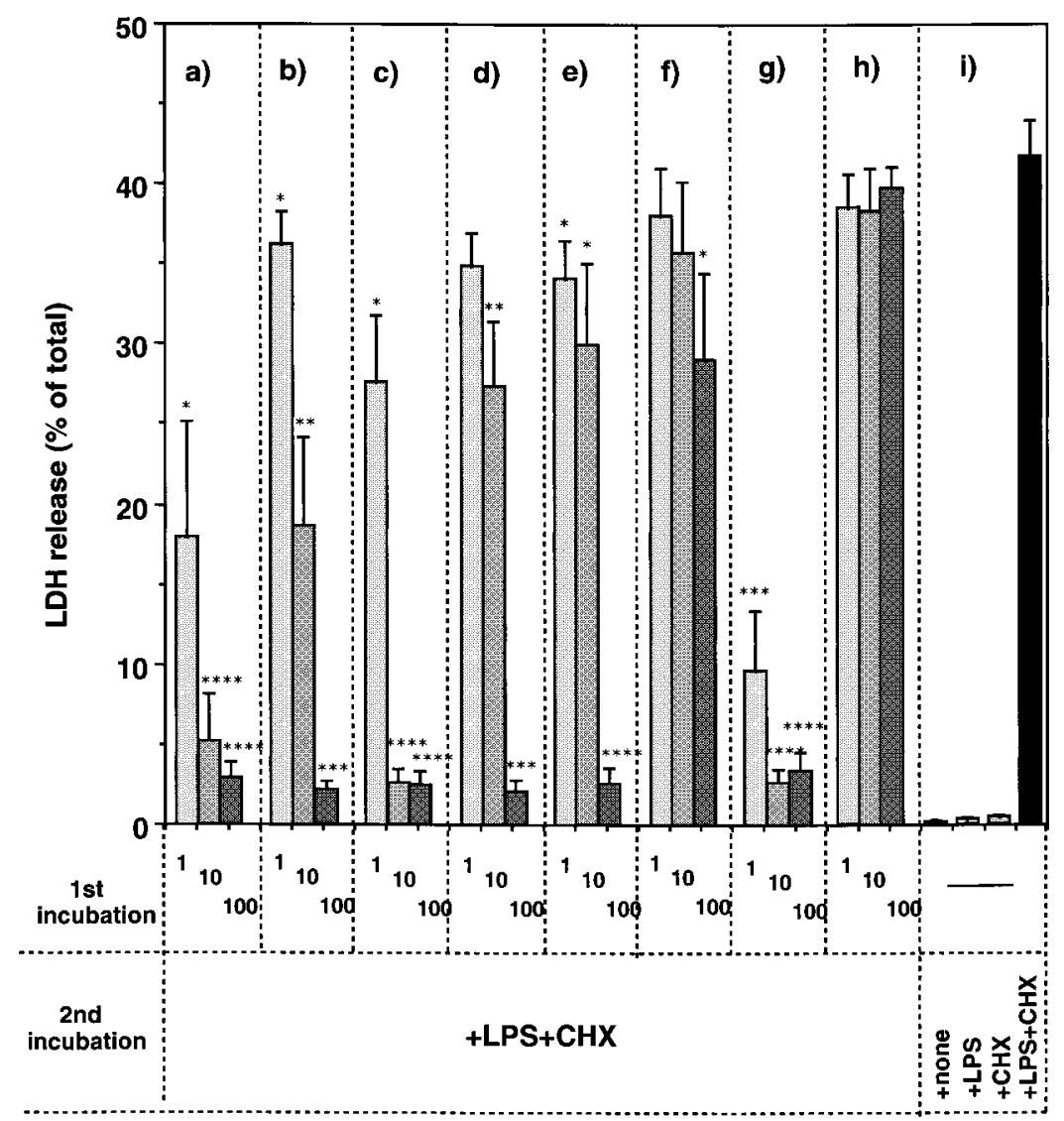

Fig. 3. Effects of Various LPS Analogs on the Induction of Tolerance to the Cytotoxicity Induced by LPS and CHX

Cells were pretreated with 1-100 ng/ml wild type smooth LPS (a), Rc-LPS (b), Rd-LPS (c), or Re-LPS (d) from S. minnesota, di-phosphoryl-lipid A (e), monophosphoryl-lipid A (f), or wild type smooth LPS (g) or alkaline-treated detoxy-LPS (h) from E. coli O55:B5 at $37^{\circ} \mathrm{C}$ for $90 \mathrm{~min}$. Then the cells were washed, and incubated with $100 \mathrm{ng} / \mathrm{ml} \mathrm{LPS}$ and $10 \mu \mathrm{g} / \mathrm{ml} \mathrm{CHX}$ for a further $4 \mathrm{~h}$, and then the LDH release was examined as described in the text. As positive and negative controls, cells were treated with nothing, either LPS or CHX alone, or both LPS and CHX for $4 \mathrm{~h}$ but without preincubation for $90 \mathrm{~min}$ (i). The significance of differences between LPS + CHX (i) and each sample was estimated by means of Student's $t$-test, and is shown as $*(p<0.05), * *(p<0.02), * * *(p<0.01)$, or $* * * *(p<0.001)$.

TNF- $\alpha,{ }^{21)}$ did not suppress the LDH release in the second incubation with LPS and CHX. On the other hand, LPS-pretreated macrophages showed significant and remarkable reduction of the LDH release (Fig. 4B). Moreover, the addition of an anti-mouse TNF- $\alpha$ neutralyzing antibody in the first incubation with LPS did not affect the induction of tolerance, nor did the addition of recombinant mouse TNF- $\alpha$ in the first incubation affect the resistance to the cytotoxicity (the first incubation with nothing, and the second incubation with $100 \mathrm{ng} / \mathrm{ml}$ LPS and $10 \mu \mathrm{g} / \mathrm{ml}$ CHX resulted in $65.3 \pm 2.8 \%$ LDH release; the first incubation with $10 \mathrm{ng} / \mathrm{ml}$ LPS and the second incubation with LPS and CHX, $6.1 \pm 0.3 \%$; the first incubation with LPS $+0.02 \mu \mathrm{g} / \mathrm{ml}$ an anti-mTNF- $\alpha$ neutralyzing antibody and the second incubation with LPS and CHX, $5.5 \pm 1.1 \%$; and the first incubation with $100 \mathrm{ng} / \mathrm{ml} \mathrm{rm}$ TNF- $\alpha$ and the second incubation with LPS and CHX, $72.2 \pm 1.9 \%$, respectively; results for a typical experiment of three independent ones). These results show that this tolerance to the cytotoxicity is not mediated by some activated macrophage products, especially TNF- $\alpha$, suggesting that LPS-treated macrophages themselves exhibit tolerance.

Next, we examined the possibility of changes in LPS binding and CD14 expression ${ }^{26)}$ on the tolerant macrophage cell surface, because endotoxin-tolerance has been reported to depend on down-regulation of LPS-receptors. ${ }^{27)}$ As shown in Fig. 5, neither the FITC-LPS-binding to the macrophages (A) nor the expression of CD14 (B) was affected by preincubation with LPS. Rather the both FITC-LPS binding and CD14 expresion seemed to be elevated to some extents by preincubation with LPS. These results suggest that the acquisition of resistance to the cytotoxicity is not dependent on the decreased binding of LPS to the cells but rather on subsequent alternations in LPS-signal transduction.

To examine this idea further, we investigated the cellular changes in the second incubation with LPS and CHX, especially those of MAP kinases in LPS-tolerant macrophages, because we previously found that sustained phosphorylation of MAP kinases was observed in macrophages under LPS-induced cytotoxicity ${ }^{25}$ ) and another laboratory has reported the down-regulation of MAP kinase activity in endotoxin-tolerance concerning TNF- $\alpha$ production in macrophages. ${ }^{28)}$ As shown in Fig. 6a, phosphorylation of p38 had occurred by 7.5 min after the addition of LPS and CHX, and a high level of phosphorylation continued until $90 \mathrm{~min}$ when the cells were preincubated without LPS. Similar results were obtained as to the ability of p38 MAP kinase to phosphorylate MAPKAPK2 whose activity was examined by phosphorylation of hsp27 in vitro (Fig. 6b)..$^{29,30)}$ In endotoxin-tolerant macrophages preincubated with $10 \mathrm{ng} / \mathrm{ml}$ LPS for $90 \mathrm{~min}$, however, both the phosphorylation and activity of p38 MAP kinase were much reduced in the second incubation with LPS and CHX (Figs. 6e, f), as compared with those in endotoxin- 

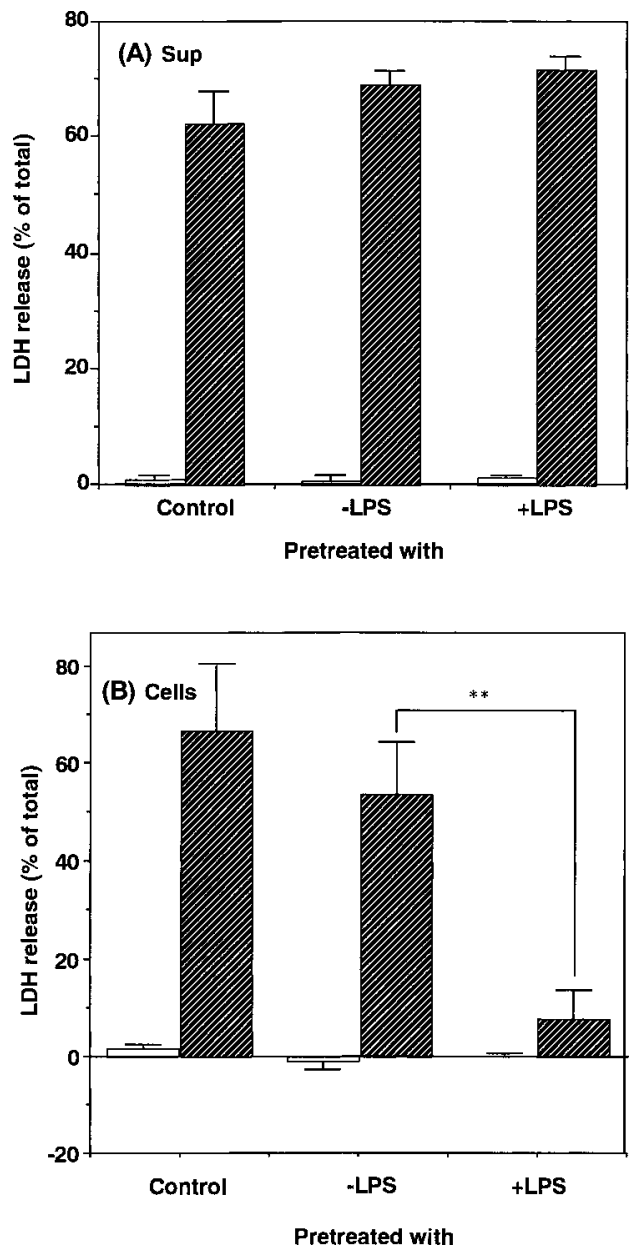

Fig. 4. Involvement of Soluble or Cellular Factors from LPS-Pretreated Cells in the Induction of Tolerance toward the Cytotoxicity Induced by LPSand CHX-Treatment

(A) Cells were treated without or with $10 \mathrm{ng} / \mathrm{ml}$ LPS for $90 \mathrm{~min}$, and the culture supernatants were collected. Aliquots of the supernatants were transferred to the chambers with new recipient cells, which were then incubated without (open columns) or with (hatched columns) $100 \mathrm{ng} / \mathrm{ml}$ LPS and $10 \mu \mathrm{g} / \mathrm{ml}$ CHX for a further $4 \mathrm{~h}$. Finally, the LDH release was examined, the results being shown as the means \pm S.E. for three independent experiments. (B) Cells were pretreated without or with $10 \mathrm{ng} / \mathrm{ml}$ LPS for $90 \mathrm{~min}$, washed throughly with the medium, and then incubated without or with $100 \mathrm{ng} / \mathrm{ml} \mathrm{LPS} \mathrm{and} 10 \mu \mathrm{g} / \mathrm{ml} \mathrm{CHX}$ for a further $4 \mathrm{~h}$. The symbols are the same as in (A), and the results are the means \pm S.E. for three independent experiments. In the both figures, control means the cells treated without preincubation but incubated without or with $100 \mathrm{ng} / \mathrm{ml} \mathrm{LPS}$ and $10 \mu \mathrm{g} / \mathrm{ml} \mathrm{CHX}$ at $37^{\circ} \mathrm{C}$ for $4 \mathrm{~h}$. The significance of differences was estimated by means of Student's $t$-test, and is shown as $* *(p<0.02)$.

non-tolerant macrophages (Figs. 6a, b). These results show that the LPS response is much reduced in LPS-tolerant macrophages on the phosphorylation of p38 MAP kinase. Similar decreases in the phosphorylation of other MAP kinases, JNK and Erk1/Erk2, were also observed in LPS-pretreated macrophages (Figs. 6g, h), showing that a reduced LPS-response includes the down-regulation of the phosphorylations of the above three MAP kinases, as compared with LPS-non-treated macrophages (Figs. 6c, d).

Sustained Phosphorylation of p38 MAP Kinase is Critical for Induction of the Cytotoxicity of LPS We next examined the phosphorylation of MAP kinases such as p38, JNK and Erk1/Erk2 in the first incubation with LPS further, because MAP kinases have been reported to play important roles in LPS-signal transduction, as they do in their activated, namely phosphorylated forms. ${ }^{31)}$ The phosphorylation of JNK gave two peaks, the first was at $15 \mathrm{~min}$ and the second at
(A)
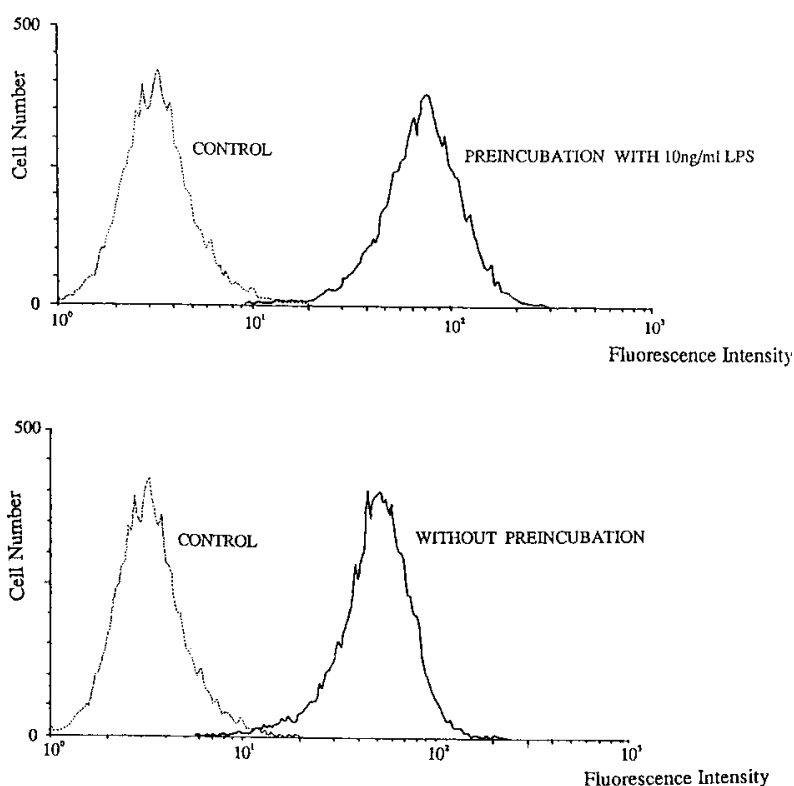

(B)
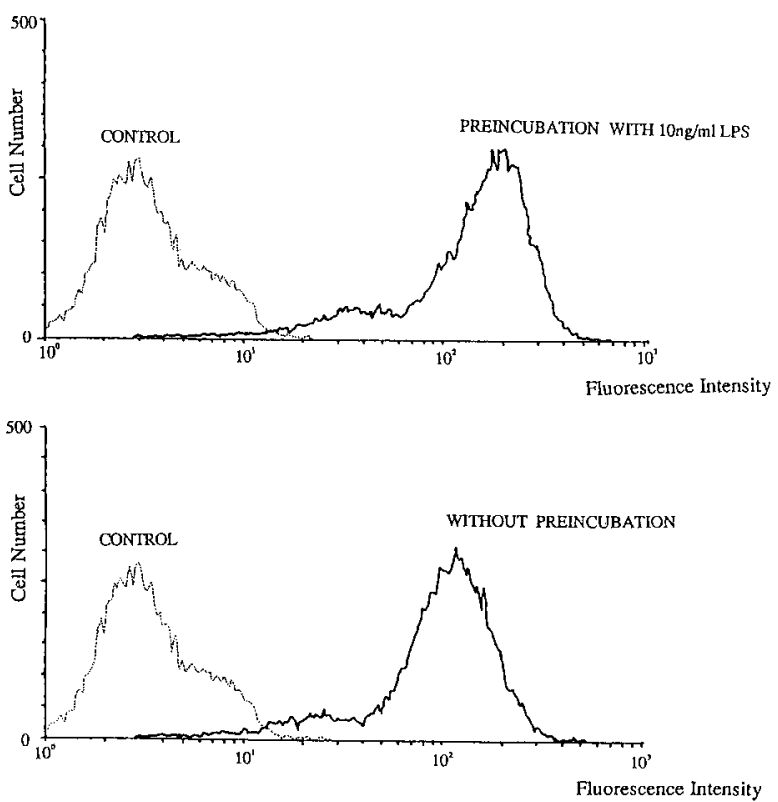

Fig. 5. Changes in LPS-Binding Activities of Cells after Preincubation with LPS

(A) Cells were preincubated with $10 \mathrm{ng} / \mathrm{ml} \mathrm{LPS}$ at $37^{\circ} \mathrm{C}$ for $90 \mathrm{~min}$, chilled on ice, and washed with fresh medium thoroughly, and then $100 \mathrm{ng} / \mathrm{ml}$ FITC-labeled LPS was added to the cultures, followed by incubation at $0^{\circ} \mathrm{C}$ for $4 \mathrm{~h}$. Binding of FITC-labeled LPS to the cell surface was analyzed with FACScan by sorting 20000 intact cells (upper panel) as described in the text. As a control, analysis of FITC-LPS binding to the cells without preincubation was also performed (lower panel). The CONTROL in (A) means the profile of staining of the cells without addition of either FITC-LPS or LPS. (B) Cells were treated as described in (A), but the expression of CD14 on the cell surface was examined with a monoclonal anti-mouse CD14 antibody followed by an FITC-labeled anti-rabbit IgG antibody (upper panel). As a control, cells without preincubation were stained similarly (lower panel). The CONTROL in (B) means the profile of staining of the cells without addition of either an anti-CD14 antibody or LPS, but with an FITC-labeled anti-rabbit IgG antibody. 

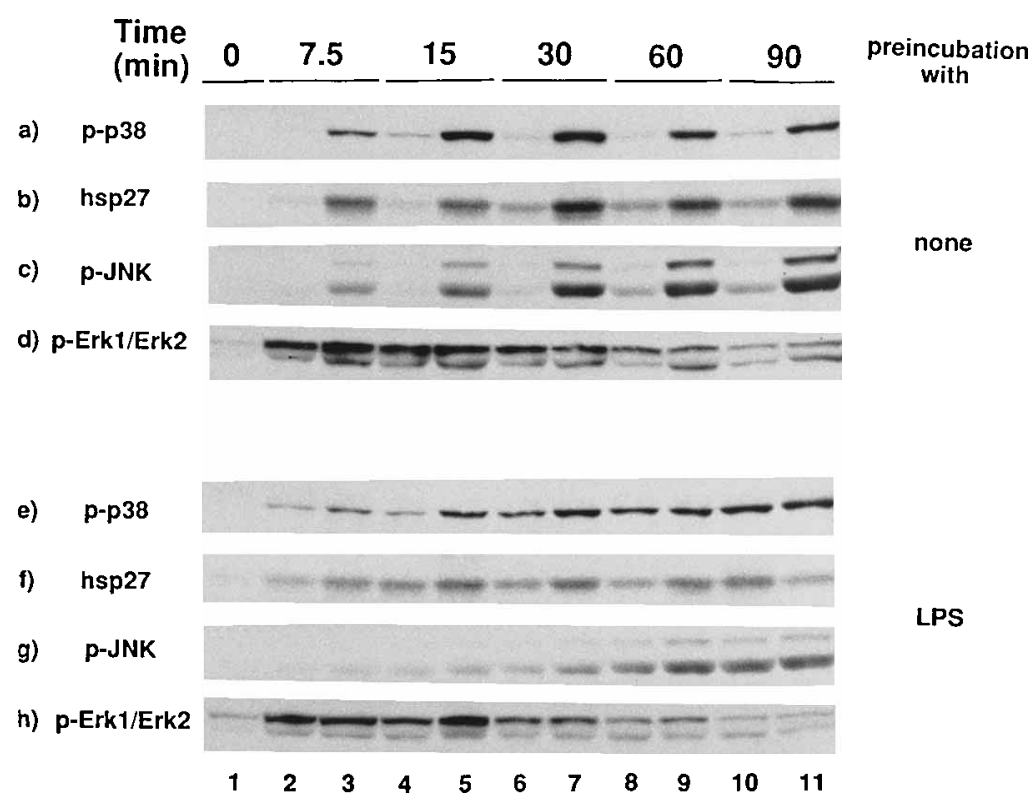

Fig. 6. Time-Courses of Phosphorylation of p-38, JNK and Erk1/Erk2 MAP Kinases, and Changes in the Kinase Activity of p38 Induced by LPS and CHX in Endotoxin-Tolerant Macrophages

Cells were pretreated without $(\mathrm{a}-\mathrm{d})$ or with $(\mathrm{e}-\mathrm{h}) 10 \mathrm{ng} / \mathrm{ml}$ LPS for $90 \mathrm{~min}$, and then washed six times with the medium. The cells were incubated further without (lanes 1,2 , $4,6,8,10$ ) or with (lanes $3,5,7,9,11) 100 \mathrm{ng} / \mathrm{ml}$ LPS in the absence (lane 1) or presence (lanes $2-11$ ) of $10 \mu \mathrm{g} / \mathrm{ml} \mathrm{CHX} \mathrm{for} \mathrm{the} \mathrm{times} \mathrm{indicated} \mathrm{on} \mathrm{the} \mathrm{top.} \mathrm{Finally,} \mathrm{the} \mathrm{cells} \mathrm{were}$ lysed, and the extracts were subjected to SDS-PAGE/Western blotting with anti-dual-phospho p38 antibodies (a, e), anti-dual-phospho JNK antibodies (c, g), or anti-dual-phospho Erk1/Erk2 antibodies $(\mathrm{d}, \mathrm{h})$. MAPKAPK2 kinase assays were performed with hsp27 (b, d) as a substrate as described in the text. The results are for a typical experiment of more than two independent ones.

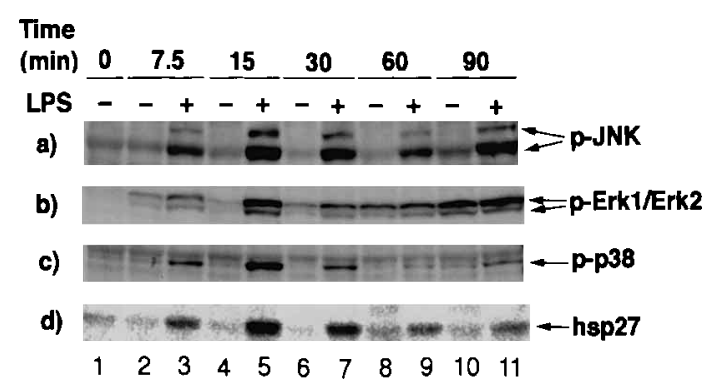

Fig. 7. Changes in the Phosphorylation of MAP Kinases in Macrophages on Treatment with LPS

The phosphorylation of JNK (a), Erk1/Erk2 (b), and p38 (c) MAP kinases, and MAPKAPK2 (d) was examined. Cells were treated without (lanes 1, 2, 4, 6, 8, 10) or with (lanes $3,5,7,9,11) 10 \mathrm{ng} / \mathrm{ml} \mathrm{LPS}$ at $37^{\circ} \mathrm{C}$ for the times indicated on the top. Finally, the cells were lyzed, and the extracts were subjected to SDS-PAGE/Western blotting as described in the text with polyclonal anti-dual-phospho JNK antibodies (a), polyclonal anti-dual-phospho Erk1/Erk2 antibodies (b), or polyclonal anti-dual-phospho p38 antibodies (c). For the detection of phosphorylated MAPKAPK2, cell extracts were immunoprecipitated with anti-MAPKAPK2 antibodies, and then the resultant MAPKAPK2 immune complex was subjected to an in vitro kinase assay with hsp27 as a substrate (d), as described in the text.

90 min (Fig. 7a). However, an increase in the phosphorylation of $\mathrm{p} 38$ or Erk1/Erk2 was observed at $7.5 \mathrm{~min}$ after the addition of $10 \mathrm{ng} / \mathrm{ml} \mathrm{LPS}$, with a peak at $15 \mathrm{~min}$, as shown in Figs. 7b, c. Although phosphorylation of Erk1/Erk2 seemed to increase again at $90 \mathrm{~min}$ (Fig. $7 \mathrm{~b}$ ), this was not dependent on the LPS action but rather on the replacement with fresh medium with FBS, because the levels of phosphorylation of Erk1/Erk2 at $90 \mathrm{~min}$ were similar in the presence and absence of LPS. On the other hand, the peak of p38 MAP kinase activity as to the phosphorylation of a downstream kinase, MAPKAPK2, was at $15 \mathrm{~min}$, the level then gradually decreasing by $90 \mathrm{~min}$ after LPS addition (Fig. 7d). These results show that the phosphorylation responses of these three MAP kinases to LPS are completed within $90 \mathrm{~min}$ in the first incubation. These results together with those in Fig. 2B suggest the possibility that the transduction of LPS signals through MAP kinases in this period is necessary for induction of the LPS-tolerance to the cytotoxicity with LPS and CHX in the second incubation.

We have reported that transduction of LPS-signals through p38 MAP kinase activity to downstream targets was needed for macrophages to avoid cell death ${ }^{25}$ before this activity was inhibited by SB202190, an inhibitor of p38 MAP kinase. ${ }^{32-35)}$ Then, we examined the possibility that the activity of p38 MAP kinase among the three MAP kinases selectively regulates endotoxin-tolerance to the cytotoxicity. In our previous experiments, SB202190 specifically suppressed the LPS-induced p38 MAP kinase activity, which should activate MAPKAPK2, and the subsequent phosphorylation of hsp27 both in vivo and in vitro. ${ }^{25)}$ Moreover, SB202190 is a reversible inhibitor of p38 MAP kinase, ${ }^{32)}$ and thus can be removed by washing the macrophages with fresh medium six times under the conditions employed in our TNF $\alpha$ experiment (data not shown). The addition of $30 \mu \mathrm{M} \mathrm{SB202190} \mathrm{to}$ the macrophages in the first 90 min incubation with LPS resulted in the not-significantly reduced LDH release caused by LPS and CHX in the second incubation (Fig. 8b), although the first incubation with LPS in the absence of SB202190 induced the tolerance to the cytotoxicity (Fig. 8a). However, SB202474, an inactive analog of SB202190, ${ }^{32}$ which had no effect on $\mathrm{p} 38$ MAP kinase activity in vivo or in vitro in our experiments, ${ }^{25}$ ) showed little effect on the increased LDH release at $30 \mu_{\mathrm{M}}$ (Fig. 8c). These results seemed to suggest that the activity of p38 MAP kinase is intrinsically involved in the induction of the endotoxin-tolerance in this experiment. However, as shown in Fig. 8b, the second incubation with CHX alone after the first incubation with LPS and SB202190 induced similar LDH release to that 


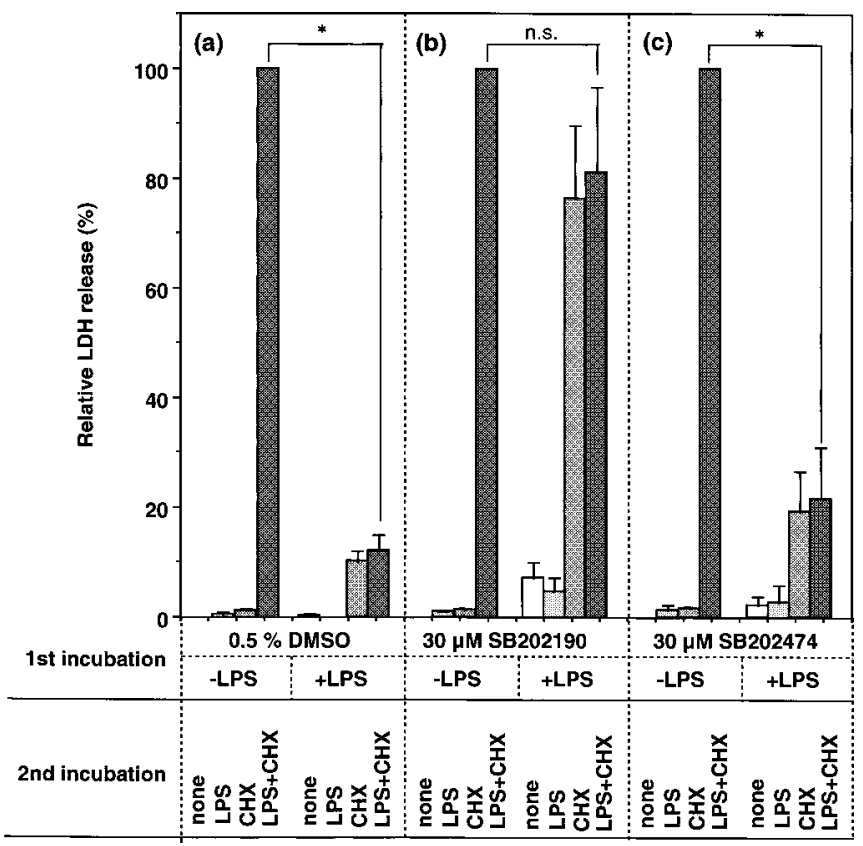

Fig. 8. Modulation of the Inhibition of the Cytotoxicity by Pretreatment with SB202190 together with LPS

Cells were treated with $0.5 \%$ DMSO (a), $30 \mu_{\mathrm{M}} \mathrm{SB} 202190$ (b), or $30 \mu_{\mathrm{M}} \mathrm{SB} 202474$ (c) for $15 \mathrm{~min}$, and then incubated without or with $10 \mathrm{ng} / \mathrm{ml} \mathrm{LPS} \mathrm{for} 90 \mathrm{~min}$. Then the cells were washed six times, and the second incubation was performed with nothing, $100 \mathrm{ng} / \mathrm{ml}$ LPS, $10 \mu \mathrm{g} / \mathrm{ml} \mathrm{CHX}$, or LPS + CHX for a further $4 \mathrm{~h}$. Finally, the LDH release was examined as described in the text. The results are shown as relative LDH release $(\%)$, which was calculated taking the LDH release for the positive control as $100 \%$ and that for the negative control as $0 \%$ in each experiment. The results are the means \pm S.E. for more than three independent experiments. The significance of differences was estimated by means of Student's $t$-test, and is shown as $*(p<0.001)$ or n.s. (not-significant).

with both LPS and CHX. These results imply that this phenomenon is not simply due to the reversal of the endotoxintolerance to the cytotoxicity with LPS and CHX caused by p38 MAP kinase inhibition with SB202190 in the first incubation. Rather, it is suggested that the LDH release may be induced under the conditions where the macrophages are pretreated with LPS and SB202190 in the first incubation, followed by treatment with $\mathrm{CHX}$ alone in the second incubation. However, LPS-signals in the first incubation still seem to have critical roles, because the first incubation with SB202190 alone did not induce the cytotoxicity even after the second incubation with CHX.

To confirm the results in Fig. 8, we examined the dosedependency with SB202190 in the first incubation with $10 \mu \mathrm{g} / \mathrm{ml}$ LPS on the induction of LDH release in the second incubation with either LPS and CHX or CHX alone. As shown in Fig. 9A, similar release of LDH was observed depending on the dose of SB202190 during the second incubation with $\mathrm{CHX}$ in the presence or absence of LPS. However, LPS and SB202474 showed little effect on the subsequent release of LDH from the cells treated with LPS and CHX. On the other hand, the effect of the second incubation with $\mathrm{CHX}$ alone after the treatment with LPS +SB202190 depended upon CHX concentrations (Fig. 9B).

Next, we examined the changes in MAP kinases during the second incubation with nothing, CHX alone, or both LPS and CHX. As shown in Fig. 10, the addition of SB202190 in the first incubation together with LPS resulted in a high level of phosphorylation of p38 MAP kinase in the second incuba-
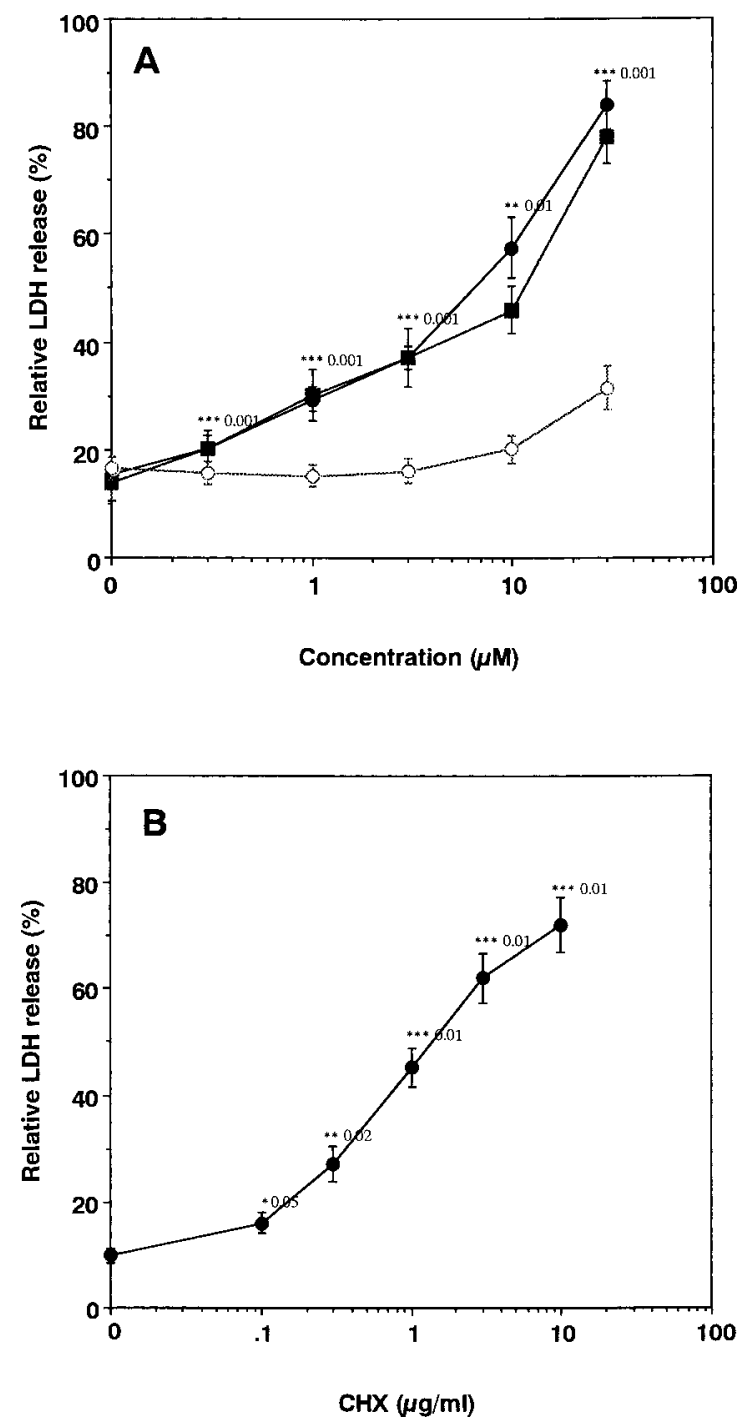

Fig. 9. Potentiation of the Cytotoxic Effect of CHX on Preincubation of Macrophages with SB202190 in the Presence of LPS

(A) Cells were incubated with various concentrations of SB202190 (closed symbols) or SB202474 (open circles) at $37^{\circ} \mathrm{C}$ for $15 \mathrm{~min}$, and then treated with $10 \mathrm{ng} / \mathrm{ml}$ LPS for $90 \mathrm{~min}$. After complete washing off of the reagents from the cells, $100 \mathrm{ng} / \mathrm{ml} \mathrm{LPS}$ and $10 \mu \mathrm{g} / \mathrm{ml} \mathrm{CHX} \mathrm{(closed} \mathrm{circles} \mathrm{and} \mathrm{open} \mathrm{circles),} \mathrm{or} \mathrm{CHX} \mathrm{alone} \mathrm{(closed} \mathrm{squares)} \mathrm{was}$ added to the culture, and then the cells were incubated for a further $4 \mathrm{~h}$. As a negative and a positive control, cells were incubated first with $0.5 \%$ DMSO alone for 15 and then $90 \mathrm{~min}$, washed repeatedly, and then reincubated without or with LPS and CHX for $4 \mathrm{~h}$, respectively. The results are shown as relative LDH release (\%), which was calculated taking the LDH release for the positive control as $100 \%$ and that for the negative control as $0 \%$ in each experiment. The means \pm S.E. for three independent experiments are shown. The significance of differences was estimated by means of Student's $t$-test, and is shown as $* *(p<0.01)$ or $* * *(p<0.001)$. (B) Cells were treated with $30 \mu \mathrm{M}$ SB202190 at $37^{\circ} \mathrm{C} 15 \mathrm{~min}$, and then $10 \mathrm{ng} / \mathrm{ml}$ LPS was added to the culture, and the cells were incubated for $90 \mathrm{~min}$. Then the cells were washed completely and incubated with various concentrations of $\mathrm{CHX}$ for $4 \mathrm{~h}$, and then the relative $\mathrm{LDH}$ release was examined as described in (A). As a control, the first incubation with $0.5 \%$ DMSO and subsequent second incubation with $10 \mu \mathrm{g} / \mathrm{ml} \mathrm{CHX}$ alone exhibited $4.3 \pm 0.5 \%$ of the relative $\mathrm{LDH}$ release. The results are the means \pm S.E. for three independent experiments, and the significance of differences was estimated by means of Student's $t$-test, and is shown as $*(p<0.05), * *(p<0.02)$, or $* * *(p<0.01)$

tion with LPS + CHX for 60 min (Fig. 10a, lane 12) similarly to in the control without LPS-preincubation (Fig. 10a, lane 9). Moreover, the second incubation with $\mathrm{CHX}$ alone also gave a similar high level of phosphorylation of p38 MAP kinase (Fig. 10a, lane 11), when the cells were pretreated with both LPS and SB202190. However, the first incubation with LPS and DMSO, a vehicle for SB202190 and SB202474, or SB202474, resulted in the phosphorylation of p38 MAP ki- 


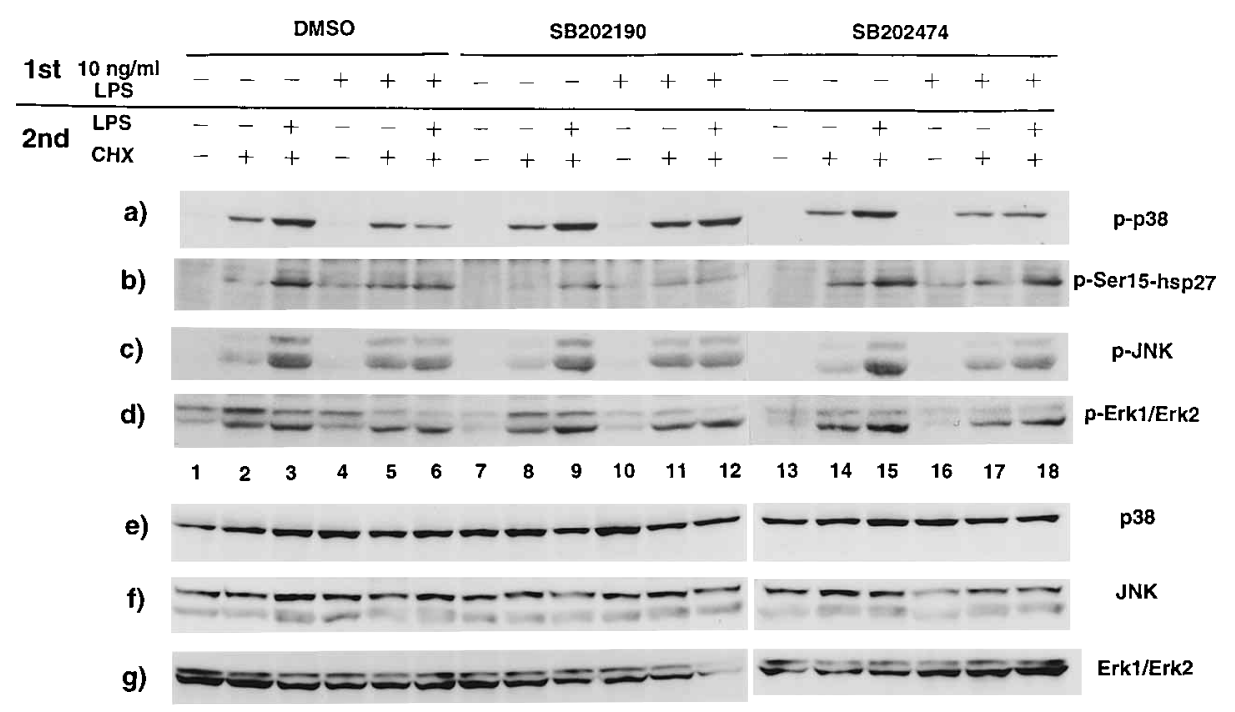

Fig. 10. SB202190-Induced Up-Regulation of Prolonged Phosphorylation of p38 in the Second Incubation with LPS and CHX

Cells were treated with 0.5\% DMSO (lanes 1-6), $30 \mu \mathrm{M}$ SB202190 (lanes 7-12), or $30 \mu \mathrm{M}$ SB202474 (lanes 13-18) for 15 min, and then incubated without (lanes 1-3, 7$9,13-15$ ) or with (lanes $4-6,10-12,16-18) 10 \mathrm{ng} / \mathrm{ml} \mathrm{LPS} \mathrm{for} 90 \mathrm{~min}$. Then the cells were washed six times, and incubated without (lanes $1,4,7,10,13,16)$ or with 10 $\mu \mathrm{g} / \mathrm{ml}$ CHX in the absence (lanes $2,5,8,11,14,17$ ) or presence (lanes $3,6,9,12,15,18)$ of $100 \mathrm{ng} / \mathrm{ml} \mathrm{LPS} \mathrm{for} \mathrm{a} \mathrm{further} 60 \mathrm{~min}$. Finally, the phosphorylation of p38 (a), hsp27 at ${ }^{15} \mathrm{Ser}$ (b), JNK (c), and Erk1/Erk2 (d) was detected as described in Fig. 3. The control Western blots for total p38 (e), JNK (f) and Erk1/Erk2 (g) are also shown from the same corresponding samples as shown in (a) (d). The results are for a typical experiment of more than five independent ones.

nase at a down-regulated level (Fig. 10a, lane 6 vs. 3, and lane $18 v s .15$, respectively). On the other hand, phosphorylation of JNK and Erk1/Erk2 remained at down-regulated levels on treatment with LPS and either SB202190, DMSO or SB202474 (Figs. 10c, d). Similar results were obtained after the second incubation of the cells for $90 \mathrm{~min}$ (data not shown). Under these conditions, however, activity of a downstream kinase of $\mathrm{p} 38$, MAPKAP2, did not correlated with the levels of phosphorylation of p38 (Fig. 10b), suggesting that sustained phosphorylation but not prolonged activity of $\mathrm{p} 38$ MAP kinase is important for the induction of cytotoxicity. These changes in the phosphorylation of the three MAP kinases were not observed in the control Western blots of the total MAP kinases (Figs. 10e-g), although only Erk1/Erk2 in reversal of the LPS-toleralized state by SB202190 (Fig. $10 \mathrm{~g}$, lane 12) showed significant reduced level.

These results show a possible correlation between the induction of the cytotoxicity of LPS (Fig. 8) and the sustained phosphorylated form of p38 MAP kinase at $60 \mathrm{~min}$ (Fig. 10), suggesting that continuation of LPS-induced phosphorylation of p38 MAP kinase triggers the apoptotic pathway in macrophages.

\section{DISCUSSION}

In the present study, we showed novel endotoxin-tolerance to the macrophage cytotoxicity which was preceded by apoptosis induced by LPS and CHX; pretreatment with $1 \mathrm{ng} / \mathrm{ml}$ LPS, the $1 / 100$ of the concentration of LPS for induction of the cytotoxicity, provided resistance to the cell damage caused by LPS and CHX, and thus greatly reduced the LDH release in the second incubation (Fig. 2A). For induction of the tolerance, LPS in the first incubation required the active structure of lipid A (Fig. 3), which has been shown to be necessary for a variety of LPS actions ${ }^{36,37)}$ including cytotoxic effect of LPS with CHX, ${ }^{38)}$ and neither LPS detoxified by alkaline treatment nor mono-phosphoryl lipid A caused induc- tion of the resistance (Fig. 3).

Concerning the mechanism underlying the induction of this endotoxin-tolerance, neither involvement of soluble factors including TNF- $\alpha$ from the LPS-treated macrophages (Fig. 4A) nor a decrease in binding of LPS to the cells (Figs. $5 \mathrm{~A}, \mathrm{~B}$ ) was shown. These results suggest that this tolerance is regulated through alteration of intracellular LPS signals following the binding of LPS to the cells. Among them, phosphorylation of MAP kinases in the second incubation with LPS and CHX was down-regulated by the first incubation with LPS (Fig. 6), suggesting that the target molecules that are regulated by the first challenge with LPS reside in LPS signaling pathways upstream of MAP kinases, although they remain largely unknown.

In addition, our attempts to block the induction of endotoxin-tolerance by inhibiting LPS signal transduction pathways in the first incubation suggested that p38 MAP kinase activity played an important role; when an inhibitor of $\mathrm{p} 38$ MAP kinase, SB202190, was added in the first incubation with LPS, it seemed to result in reversal of the tolerance and the LDH release was recovered to the control level without LPS-pretreatment (Fig. 8). However, SB202474, an inactive analog of SB202190, did not. This remarkable effect of SB202190 was, however, not only directed to cells treated with LPS + CHX but also to ones treated with CHX alone in the second incubation (Figs. 8, 9), suggesting that SB202190 did not simply reverse the endotoxin-tolerance in the first incubation. Instead, analysis of phospho-p38 MAP kinase (Fig. 10a) revealed that SB202190 in the first incubation with LPS elevated the levels of phosphorylation in the cells treated with LPS + CHX (lane 12) and with CHX alone (lane 11) similarly to the level in the non-tolerant positive control cells (lane 9). We have shown that treatment with LPS and $30 \mu \mathrm{M}$ SB202190 is non-toxic for macrophages, ${ }^{25)}$ and that SB202090 is removed from macrophages on repeated washing (data not shown). Under the present experimental conditions, SB202190 seemed to exert its effect by changing the 
intracellular signals of LPS which leads to altered cellular responses afterwards. Furthermore, addition of CHX in the second incubation may have resulted in augmentation of such reactions leading to the induction of the cytotoxicity as phosphorylation of p38 MAP kinase. Our preliminary experiments supported this idea by showing that simultaneous addition of $10 \mathrm{ng} / \mathrm{ml} \mathrm{LPS}, 30 \mu \mathrm{M}$ SB202190 and $1 \mu \mathrm{g} / \mathrm{ml} \mathrm{CHX}$ induced much higher release of LDH than either of the two out of these three additives during the incubation of the cells at $37^{\circ} \mathrm{C}$ for $4 \mathrm{~h}$. On the other hand, SB202190 showed the ability to enhance and sustain the level of LPS-induced phosphorylation of p38 MAP kinase, ${ }^{25)}$ and CHX increased p38 phosphorylation (Figs. 6a, 7c; 10). Perhaps the addition of CHX to a culture with LPS $+30 \mu \mathrm{M}$ SB202190 up-regulates the state of phosphorylation of p38 MAP kinase further, and it seems to reach across the threshold level for triggering cell damage.

However, the mode of action of CHX in the present experimental system does not seem to be simple. $\mathrm{CHX}$ is a potent inhibitor of protein synthesis, and it inhibited incorporation of $\left[{ }^{35}\right]$ methionine and $\left[{ }^{35}\right]$ cysteine into protein dependently on its doses either in LPS-treated or non-treated macrophages. ${ }^{21)}$ Thus CHX might inhibit induction of MAP kinase phosphatase(s) that is responsible for dephosphorylation of phosphorylated p38 MAP kinase, leading to the sustained phosphorylation of p38 after LPS-treatment. LPS itself is a strong inducer of p38 phosphorylation, which is down-regulated by pretreatment with low concentration of LPS in the 1st incubation (Fig. 6). Besides, LPS seems to be an inducer of p-p38 phosphatase that works later than $15 \mathrm{~min}$ after LPS-treatment (Fig. 7). Therefore, preincubation with LPS seems to be of critical role in the induction of endotoxin-tolerance to the cytotoxicity in the 2nd incubation with LPS and CHX, in which the extents of phosphorylated states of p-38 become lower (Fig. 6). Characterization of such protein phosphatase(s) remains to be elucidated.

In a recent study, we found novel cytotoxicity induced by LPS and a high concentration of SB202190. ${ }^{25}$ This cytotoxicity was also preceded by apoptotic changes, and in the earlier time-course, sustained phosphorylation of p38 was observed, although the ability of phosphorylated p38 MAP kinase to phosphorylate a downstream kinase, MAPKAPK2, was prevented by SB202190 completely. Furthermore, in this study, the sustained p38 phosphorylation correlated well with the induction of the cytotoxicity (Figs. 8-10), but not with the ability of the phosphorylated p38 to trigger the phosphorylation of a down-stream target, hsp27 (Fig. 10b). Overall, keeping high level of phosphorylation of LPS-induced p38 MAP kinase seems critical for induction of the cytotoxicity with LPS.

The cytotoxicity induced by LPS and CHX was induced through apoptosis (Fig. 1B), and activation of caspase-3 was observed earlier at $75 \mathrm{~min}$ after the addition of LPS and CHX. ${ }^{22,23,39)}$ The activated caspase- 3 in these macrophages was shown to be accumulated in the nuclei of macrophages, similarly to that observed for the cytotoxicity with LPS and $100 \mu \mathrm{M} \mathrm{SB} 202190 .^{25)}$ On the other hand, phosphorylated p38 MAP kinase in the macrophages had remained at a high level until 60 min after the addition of LPS and CHX (Figs. 6, 10), which was seen prior to activation of caspase-3. Once phosphorylated by treatment with LPS alone, p38 MAP kinase was translocated to the nuclei, and then it disappeared, probably due to its movement back to the cytosol or dephosphorylation in the nuclei. However, the simultaneous addition of SB202190 or CHX with LPS led to phosphorylated p38 MAP kinase being concentrated in the nuclei, although most of non-phosphorylated p38 MAP kinase was abundantly seen in the cytosol throughout the incubation (Amano et al., manuscript in preparation). We are now studying the mechanism by which phosphorylated p38 MAP kinase localizes in the nuclei, and those underlying the triggering of the activation of caspase-3 via phosphorylation of p38 MAP kinase, which is of either active or inactive kinase activity.

In conclusion, endotoxin-tolerance to the cytotoxicity of LPS is induced though down-regulation of p38 MAP kinase phosphorylation on pretreatment with LPS. This report will provide novel and useful information on the role of p38 MAP kinase in the regulation of the lethal effects of LPS in macrophages.

Acknowledgements We wish to thank Drs. Yasuhito Tanaka and Yoshiyuki Ishii for the useful discussions, Dr. Kazuhiro Nagata for the kind gift of the anti Ser $^{15}$-phosphorylated hsp27 antibodies, and Kumiko Ishii and Mari Takizawa for the technical assistance.

\section{REFERENCES}

1) Morrison D., Ryan J. L., Adv. Immunol., 28, 293-450 (1979).

2) Havel E. A., Spitalny G. L., J. Reticuloendothelial Soc., 33, 369-380 (1983).

3) Virca G. D., Kim S. Y., Glaser K. B., Ulevitch R. J., J. Biol. Chem., 264, 21951-21956 (1989).

4) Dinarello C. A., Rev. Infect. Dis., 6, 51-95 (1984).

5) Zuckerman S. H., Evans G. F., Butler L. D., Infect. Immun., 59, 2774-2780 (1991).

6) Amano F., Akamatsu Y., Infect. Immun., 59, 2166-2174 (1991).

7) Stuehr D. J., Marletta M. A., J. Immunol., 139, 518-525 (1987).

8) Fujihara M., Connolly N., Ito N., Suzuki T., J. Immunol., 152, $1898-$ 1906 (1994).

9) Okusawa S., Gelfand J. A., Ikejima T., Connolly R. J., Dinarello C. A., J. Clin. Invest., 81, 1162-1172 (1988).

10) Tracey K. J., Beutler B., Lowry S. F., Merryweather J., Wolpe S., Milsark I. W., Hariri R. J., Fahey III, T. J., Zentella A., Albert J. D., Shires G. T., Cerami A., Science, 234, 470-474 (1986).

11) van Deventer S. J. H., Büller H. R., ten Cate J. W., Aarden L. A., Hack C. E., Sturk A., Blood, 76, 2520-2526 (1990).

12) Natanson C., Eichenholz P. W., Danner R. L., Eichacker P. Q., Hoffman W. D., Kuo G. C., Banks S. M., MacVittie T. J., Parrillo J. E., J. Exp. Med., 169, 823-832 (1989).

13) Beutler B., Milsark I. W., Cerami A. C., Science, 229, 869-871 (1985).

14) Ohlsson K., Björk P., Bergenfeldt M., Hageman R., Thompson R. C., Nature (London), 348, 550—552 (1990).

15) Pfeffer K., Matsuyama T., Kündig T. M., Wakeham A., Kishihara K., Shahinian A., Wiegmann K., Ohashi P. S., Krönke M., Mak T. W., Cell, 73, 457-467 (1993).

16) Li P., Allen H., Banerjee S., Franklin S., Herzog L., Johnston C., McDowell J., Paskind M., Rodman L., Salfeld J., Towne E., Tracey D., Wardwell S., Wei F. Y., Wong W., Kamen R., Seshadri T., Cell, 80, 401-411 (1995).

17) Cavaillon J.-M., Pitton C., Fitting C., J. Endotoxin Res., 1, 21-29 (1994).

18) Freudenberg M. A., Galanos C., Infect. Immun., 56, 1352-1357 (1988).

19) Takasuka N., Tokunaga T., Akagawa K. S., J. Immunol., 146, 3824 3830 (1991).

20) Kraatz J., Clair L., Rodriguez J. L., West M. A., J. Surgical Res., 83, $158-164$ (1999). 
21) Amano F., Karahashi H., J. Endotoxin Res., 3, 415-423 (1996).

22) Karahashi H., Amano F., Exp. Cell Res., 241, 373-383 (1998).

23) Karahashi H., Amano F., J. Leukoc. Biol., 66, 689-696 (1999).

24) Lee J. C., Young P. R., J. Leukoc. Biol., 59, 152-157 (1996).

25) Karahashi H., Nagata K., Ishii K., Amano F., Biochim. Biophys. Acta, 1502, 207-223 (2000).

26) Kirkland T. N., Finley F., Leturcq D., Moriarty A., Lee J.-D., J. Biol. Chem., 33, 24818-24823 (1993).

27) Nomura F., Akashi S., Sakao Y., Sato S., Kawai T., Matsumoto M., Nakanishi K., Kimoto M., Miyake K., Takeda K., Akira S., J. Immunol., 164, 3476-3479 (2000).

28) Tominaga K., Saito S., Matsuura M., Nakano M., Biochim. Biophys. Acta, 1450, 130-144 (1999).

29) Clifton A. D., Young P. R., Cohen P., FEBS Lett., 392, 209-214 (1996).

30) Huang C.-K., Zhan L., Ai Y., Jongstra J., J. Biol. Chem., 272, 17-19 (1997).

31) Sanghera J. S., Weinstein S. L., Aluwalia M., Girn J., Pelech S. L., J.
Immunol., 156, 4457-4465 (1996).

32) Nemoto S., Xiang J., Huang S., Lin A., J. Biol. Chem., 273, $16415-$ 16420 (1998).

33) Manthey C. L., Wang S.-W., Kinney S. D., Yao Z., J. Leukoc. Biol., 64, 409-417 (1998).

34) Ajizian S. J., English B. K., Meals E. A., J. Infect. Dis., 179, 939-944 (1999).

35) Dudley D. A., Pang L., Decker S. J., Bridges A. J., Saltiel A., Proc. Natl. Acad. Sci. U.S.A., 92, 7686-7689 (1995).

36) Kotani S., Takada H., Tsujimoto M., Ogawa T., Takahashi I., Ikeda T., Otsuka K., Shimauti H., Kasai N., Mashimo J., Nagao S., Tanaka A., Tanaka S., Harada K., Nagaki K., Kitamura H., Shiba T., Kusumoto S., Imoto M., Yoshimura H., Infect. Immun., 49, 225-237 (1985).

37) Galanos C., Lüderitz O., Rietschel E. T., Westphal O., Brade H., Brade L., Freudenberg M., Schade U., Imoto M., Yoshimura H., Kusumoto S., Shiba T., Eur. J. Biochem., 148, 1-5 (1985).

38) Karahashi H., Amano F., Biol. Pharm. Bull., 21, $1102-1105$ (1998).

39) Karahashi H., Amano F., Biol. Pharm. Bull., 23, 140-144 (2000). 